AGREGAT: Jurnal Ekonomi dan Bisnis

Vol. 2, No. 2, September 2018

http://journal.uhamka.ac.id/index.php/agregat

p-ISSN: 2580-3360 e-ISSN: 2581-2874

DOI: 10.22236/agregat_vol1/is4pp306-323

Hal 306-323

\title{
DETERMINASI TARIF RETRIBUSI PASAR TRADISIONAL DENGAN PENDEKATAN WILLINGNESS TO PAY DAN PERBANDINGAN HARGA PASAR
}

\author{
Pitri Yandri \\ STIE Ahmad Dahlan Jakarta \\ E-mail: p.yandri@gmail.com
}

Diterima: 3 Juni 2018; Direvisi: 7 Juni 2018; Disetujui: 25 Juni 2018

\begin{abstract}
The new autonomous region is generally faced with the administrative adaptation problem. The adaptation is being implemented by South Tangerang Municipality. One of the adaptations is doing traditional market governance improvement to become better by setting the tarif of retribution. In theoretically, the approach to the determinate of tarif retribution can be analyzed by the variety of approaches. Two of the most widely used is the willingness to pay and market price comparative approach. Thus, this article will use those approaches to estimate traditional market tariff retribution. The results of the estimation and its elaboration are discussed further in this article

Keywords: Decentralization, Modern Market, Tangerang Selatan, Suburban, New Autonomous Region, Contingent Valuation Method
\end{abstract}

\begin{abstract}
Abstrak
Daerah otonom baru umumnya berhadapan dengan masalah adaptasi administratif. Upaya adaptasi itu sedang dilakukan oleh Kota Tangerang Selatan. Salah satu adaptasi tersebut adalah melakukan perbaikan tata kelola pasar tradisional untuk menjadi lebih baik dengan menetapkan tarif retribusi. Secara teoritik, pendekatan penentuan tarif retribusi dapat dilakukan dengan berbagai pendekatan. Dua pendekatan yang paling banyak dilakukan adalah willingness to pay dan perbandingan harga pasar. Karena itu, artikel ini akan menggunakan dua pendekatan tersebut untuk mengestimasi besaran tarif retribusi pasar tradisional. Hasil pendugaan dan elaborasinya dibahas lebih jauh dalam artikel ini. Kata Kunci: Desentralisasi, Pasar Modern, Kota Tangerang Selatan, Suburban, Daerah Otonom Baru, Contingent Valuation Method
\end{abstract}




\section{PENDAHULUAN}

Sejak era otonomi, banyak daerah yang dimekarkan. Secara normatif, pemekaran tersebut dilakukan demi mencapai kesejahteraan masyarakat. Karena diyakini pemekaran daerah adalah satu-satunya jalan untuk memperpendek rantai birokrasi pelayanan publik danmendekatkan pemerintah dengan masyarakat di daerah. Karena keyakinan itulah maka banyak daerah memekarkan diri dari kabupaten induknya dan membentuk daerah otonom baru. Namun demikian, problem rumit muncul tatkala daerah tersebut berhasil dimekarkan.Problem-problem tersebut antara lain problem administrasi pemerintahan, penataan governance untuk mencapai tata kelola yang baik, hingga masalah bagaimana sumber-sumber pendapatan daerah bisa dioptimalkan demi mencapai pembiayaan pembangunan untuk melayani masyarakat di daerahnya (Khitam, 2014). Problem tersebut juga sedang dihadapi oleh Kota Tangerang Selatan. Kota Tangerang Selatan dikenal sebagai daerah otonom yang dimekarkan pada tahun 2008 berdasarkan UU. No. 51/2008 tentang Pembentukan Kota Tangerang Selatan di Provinsi Banten tertanggal 26 November 2008. Wilayah ini adalah wilayah suburban yang berada di pinggir DKI Jakarta. Batas wilayah Kota Tangerang Selatan adalah sebelah utara berbatasan dengan Provinsi DKI Jakarta dan Kota Tangerang; sebelah timur berbatasan dengan Provinsi DKI Jakarta dan Kota Depok; sebelah selatan berbatasan dengan Kabupaten Bogor dan Kota Depok; dan sebelah barat berbatasan dengan Kabupaten Tangerang (Gambar 1).

\section{Gambar 1. Peta Lokasi Kota Tangerang Selatan}

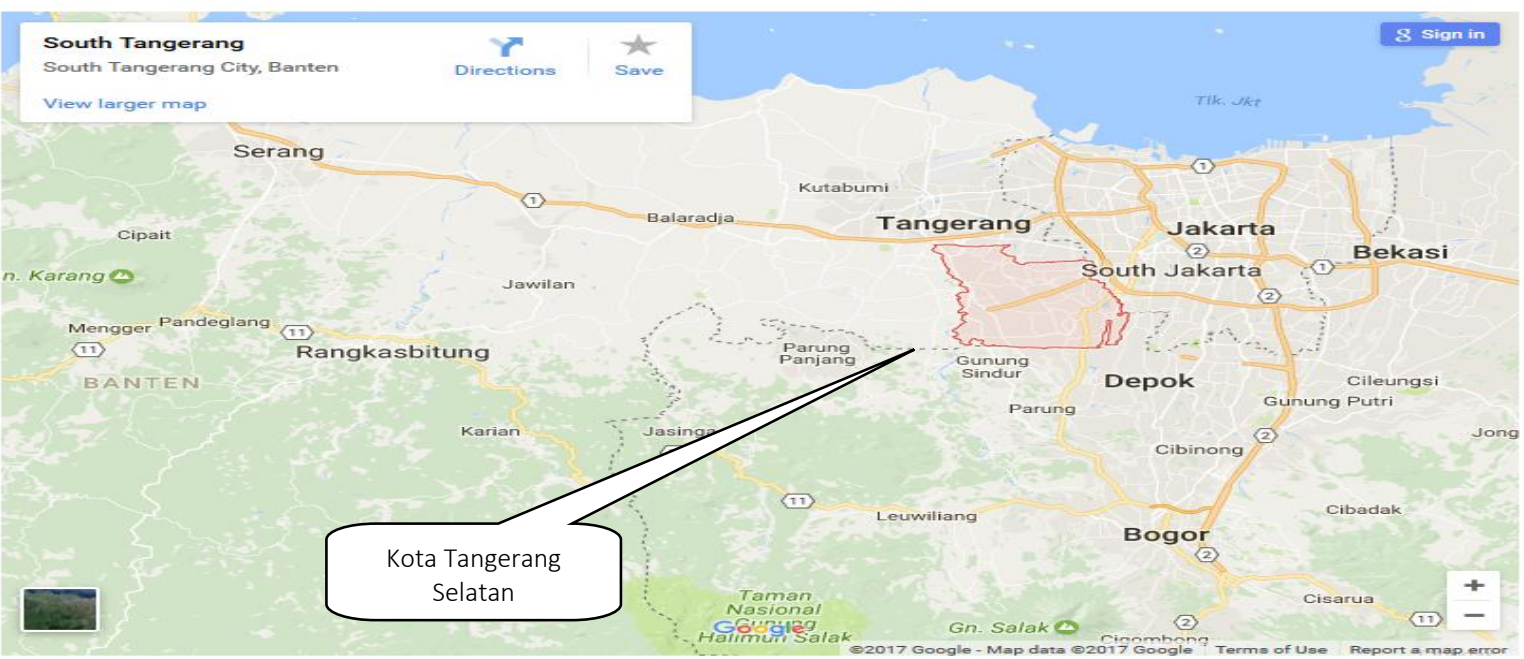


308 AGREGAT: Jurnal Ekonomi dan Bisnis

Vol. 2, No. 2 September 2018

http://journal.uhamka.ac.id/index.php/agregat

p-ISSN: 2580-3360 e-ISSN: 2581-2874

DOI: 10.22236/agregat_vol1/is4pp306-323

Hal 306-323

Upaya menyediakan pelayanan publik bermutu bagi masyarakat, setiap daerah dituntut untuk dapat membiayai sendiri ongkos yang dikeluarkan untuk menyediakan fasilitas pelayanan. Semakin tinggi kemampuan daerah untuk membiayai sendiri pembangunannya, semakin baik pula tingkat kemandirian daerah tersebut.

Dalam konteks itulah pemerintah daerah ditantang mencari berbagai terobosan perbaikan dan peningkatan basis fiskal daerah (pajak daerah dan retribusi daerah). Peningkatan pos-pos pendapatan daerah, termasuk retribusi, dengan demikian menjadi penting untuk terus dilakukan. Dalam UU. No. 28/2009 tentang Pajak Daerah dan Retribusi Daerah dijelaskan bahwa retribusi daerah dibagi menjadi tiga jenis, yaitu retribusi jasa umum; retribusi jasa usaha; retribusi perizinan tertentu.

Salah satu dari sekian banyak jenis retribusi yang diambil oleh pemerintah daerah adalah retribusi pasar. Retribusi pasar adalah "retribusi atas fasilitas pasar tradisional/sederhana yang berupa pelataran atau los yang dikelola pemerintah daerah dan khusus disediakan untuk pedagang, tidak termasuk yang dikelola perusahaan daerah pasar (Prakosa,
2005).Dalam konteks pasar, Kota Tangerang Selatan telah memiliki 9 (Sembilan) pasar tradisional yaitu: Pasar Ciputat, Pasar Serpong, Pasar Ciputat Permai, Pasar Jombang, Pasar Bintaro Sektor 2, Pasar Jengkol, Pasar Gedung Hijau, Pasar Kita Pamulang, dan Pasar Gintung.

Secara legal formal, pelimpahan kewenangan tata kelola sebagian pasar tersebut baru diserahkan oleh kabupaten induk (Kabupaten Tangerang) pada tahun 2015; dan sisanya pada tahun 2016. Karena persoalan kelambanan pelimpahan hak kepemilikan aset itulah seluruh pasar tersebut masih dalam kondisi yang memprihatinkan hingga saat ini.Pengamatan terhadap kondisi fisik pasar menunjukkan, permasalahan pasar di Tangerang Selatan mencakup antara lain: tidak ada lahan parkir; pedagang kaki lima yang tumpah ke jalan; minimnya infrastruktur pasar seperti lantai rusak dan kotor, problem drainase/saluran air; becek dan banjir; penanganan limbah/sampah pasar yang lemah; dan lain sebagainya (Gambar 2a-2c).

Masalah sekuensial yang dimulai dari perannya sebagai daerah otonom baru, yang peran itu membutuhkan berbagai penyesuaian administratif, lalu hal tersebut 
diikuti pula oleh persoalan mengadaptasi dan sekaligus memitigasi risiko sebagai daerah otonom baru. Hal tersebut mengakibatkan kebijakan publik yang ditempuh seakan berlomba dengan kecepatan ekspektasi masyarakat terhadap pemenuhan fasilitas pelayanan. Merespons hal tersebut, Pemerintah Kota Tangerang Selatan telah menggulirkan Perda No. 09/2014 tentang Retribusi Daerah. Pada periode yang sama, mereka juga telah menyusun regulasi perpasaran yang termaktub dalam Peraturan Daerah Kota Tangerang Selatan No. 4/2014 tentang Penyelenggaraan Perizinan dan Pendaftaran Usaha Perindustrian dan Perdagangan. Adapun peraturan spesifiknya tercantum dalam Peraturan Walikota Tangerang Selatan No. 2/2013 tentang Petunjuk Teknis Penataan dan Pembinaan Pasar Tradisional, Pusat Perbelanjaan dan Toko Modern.

\section{Gambar 2a. Situasi Lorong di Pasar Jombang Gambar 2b. Situasi Drainase/Saluran Air di Pasar Ciputat Permai Gambar 2c. Situasi Parkir Pasar Ciputat}

Gambar 2a

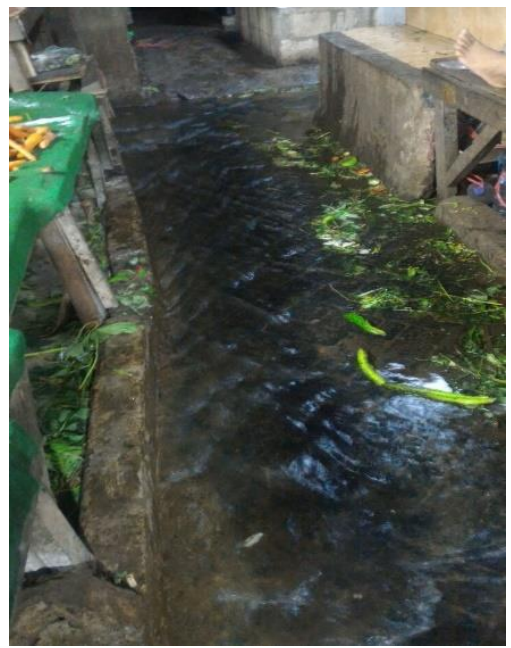

Sumber: survey, 2017
Gambar 2b

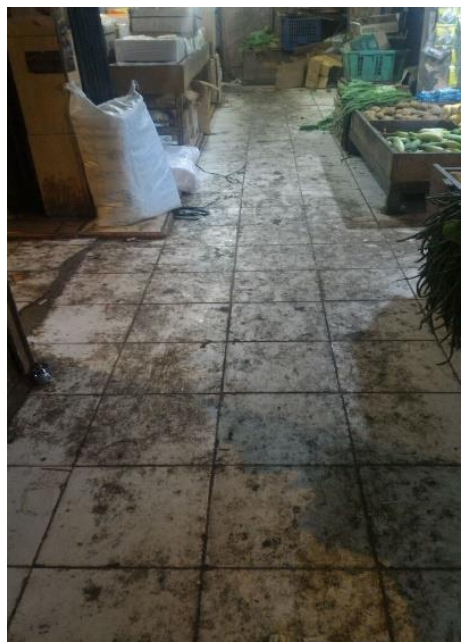

Gambar 2c

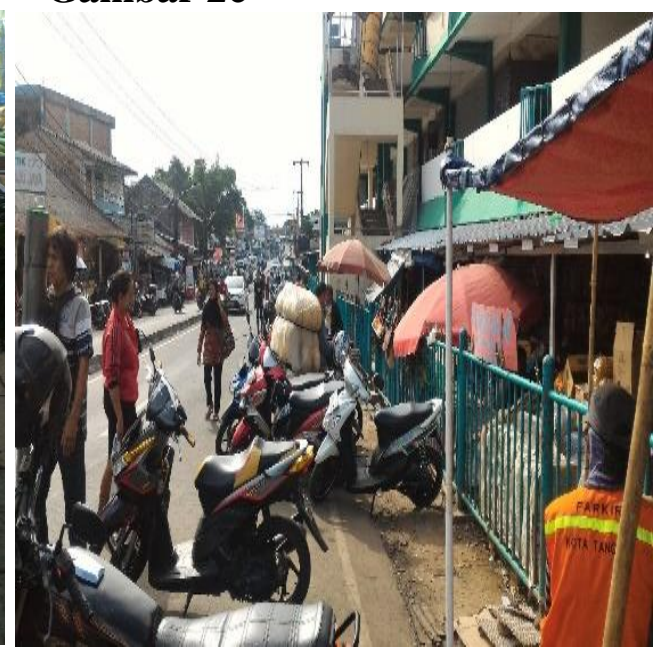

Namun demikian, sejumlah regulasi itu dinilai masih belum dapat menjawab persoalan karena regulasi yang ada hanya mengatur hal-hal yang bersifat umum. Menurut Perda tersebut, retribusi pasar digolongkan ke dalam Retribusi Jasa
Usaha (pasal 3) karena dianggap sebagai salah satu komponen retribusi sebagai akibat dari pemakaian kekayaan daerah. Jadi dalam regulasi ini, pelaku usaha yang menggunakan fasilitas pada bangunan pasar dianggap sebagai pihak yang 
310 AGREGAT: Jurnal Ekonomi dan Bisnis

Vol. 2, No. 2 September 2018

http://journal.uhamka.ac.id/index.php/agregat

p-ISSN: 2580-3360 e-ISSN: 2581-2874

DOI: 10.22236/agregat_vol1/is4pp306-323

Hal 306-323

menggunakan kekayaan daerah dan karenanya mereka wajib membayar sejumlah retribusi. Adapun besaran tarif mereka gunakan. Gambar di bawah ini adalah ilustrasi besaran tarif retribusi pasar di Tangerang Selatan.

retribusi tergantung dari luas lahan yang

\section{Gambar 3. Ilustrasi Karcis Retribusi Pasar di Tangerang Selatan}

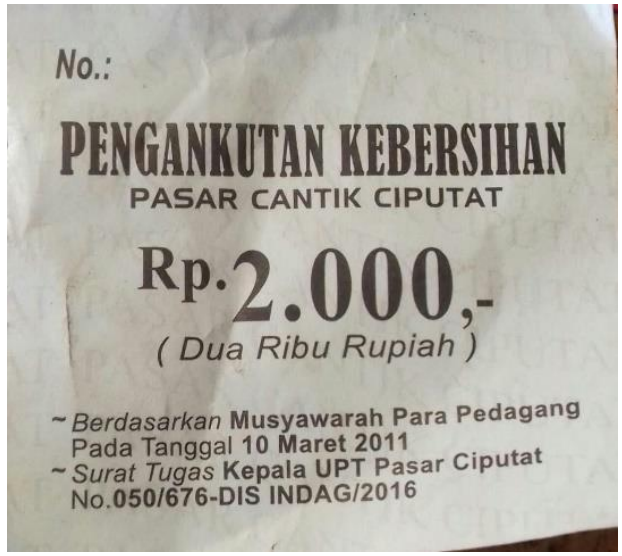

Sumber: survey, 2017

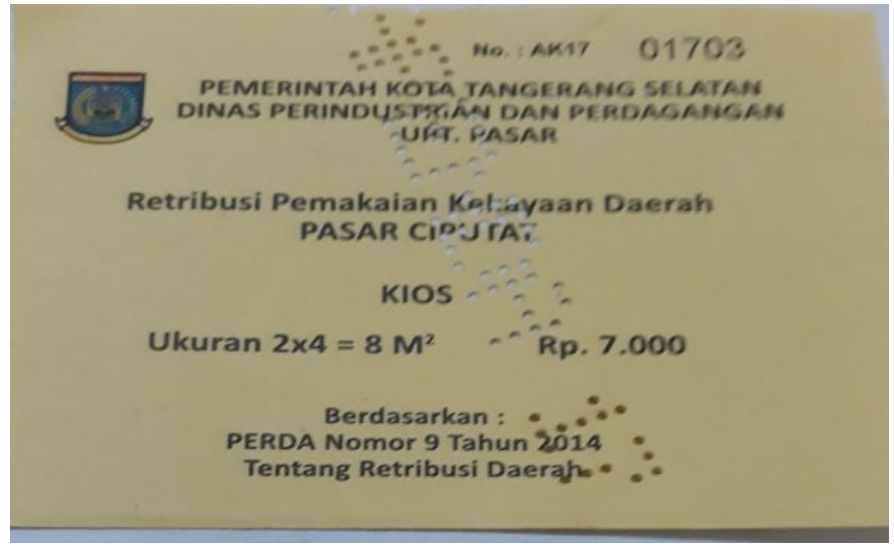

pada tahun 2017. Pada tahun yang sama, total penerimaan retribusi pasar dari empat pasar yang ada hanya mencapai $\mathrm{Rp}$. 429,922,213 Gambar 4).Kedua, banyaknya pungutan 'atas nama retribusi' yang dilakukan oleh oknum tidak bertanggungjawab; dan hal ini berdampak pada kebocoran penerimaan retribusi.

retribusi daerah hanya berkisar $0,48 \%$

Gambar 4. Penerimaan Retribusi Empat Pasar di Tangerang Selatan

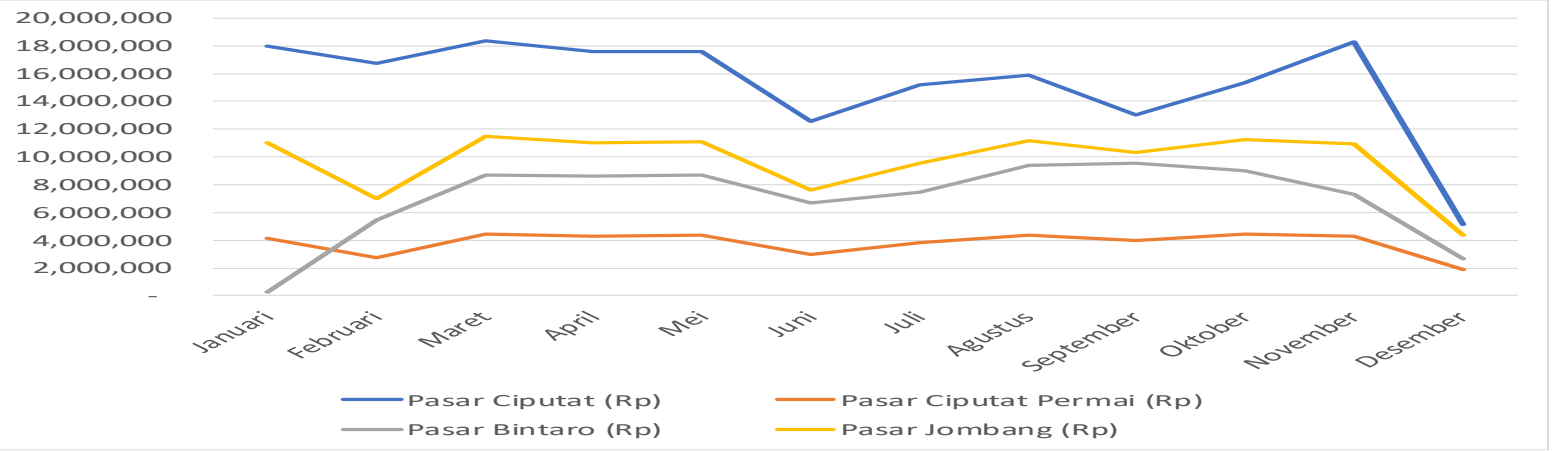

Sumber: Dinas Perindustrian dan Perdagangan Kota Tangerang Selatan, diolah; 2017.

Keterangan: data Pasar Ciputat Permai \& Pasar Jombang sampai dengan 12 Desember 2017;

data Pasar Ciputat dan Pasar Bintaro sampai dengan 8 Desember 2017. 
Rendahnya penerimaan dari retribusi pasar ini telah menjadi gejala umum di hampir seluruh kabupaten/kota di Indonesia. Studi yang terkait dengan hal ini misalnya dilakukan oleh Megawati \& Soejoto (2016) di Kab. Sidoarjo; Marselina (2013) di Kota Padang; dan Handoko (2012) di Kab. Pemalang. Dalam upaya menjawab persoalan itu, penentuan tarif yang rasional dan proporsional menjadi penting dilakukan.

Kepastian tarif ini penting dari dua sisi sekaligus: dari sisi pemerintah, kepastian tarif akan dapat memberi kepastian berapa sesungguhnya potensi ekonomi tarif retribusi pasar yang dapat berkontribusi terhadap pendapatan asli daerah; dan dari sisi pelaku usaha: kepastian tarif akan memberi kepastian berapa harga (biaya) yang harus mereka keluarkan setiap bulan; kepastian tarif akan memberi kenyamanan berinvestasi bagi pelaku usaha. Lebih dari itu, memberi kepastian tarif retribusi juga berdampak pada upaya pelestarian pasar tradisional sebagai rumah budaya (Basri et al, 2012); dan karenanya, eksistensimereka menjadi penting dalam konstelasi roda perekonomian (Putra \& Rudito, 2015), terutama roda perekonomian daerah.

Apalagi dalam konteks daerah suburban yang banyak berdiri ritel minimarket secara massif (Smadja \& Torre, 2017), mempertahankan keberadaan pasar tradisional dengan demikian menjadi kebijakan publik yang tak dapat ditawartawar lagi (Suryadarma et al, 2010).

\section{METODE PENELITIAN}

Desain penelitian menggunakan rancangan observasional. Pengumpulan data dilakukan dengan teknik survey dengan instrumen kuesioner dan wawancara. Data yang digunakan adalah data primer. Teknik sampling yang digunakan adalah purposive sampling. Pasar yang akan diamati dan informasi jumlah responden sebagaimana tergambar dalam tabel di bawah ini.

Tabel 1. Distribusi Jumlah Sampel dan Pasar yang Diamati

\begin{tabular}{lrc}
\hline \multicolumn{1}{c}{ Nama Pasar } & $\begin{array}{c}\text { Jumlah Responden } \\
\text { (orang) }\end{array}$ & Teknik Sampling yang Digunakan \\
\hline Pasar Ciputat & 10 & \\
Pasar Jombang & 7 & Purposive Sampilng \\
Pasar Serpong & 10 & \\
Pasar Ciputat-Cimanggis & 5 & \\
Pasar Kita Pamulang & 7 & \\
\hline \multicolumn{1}{c}{$\Sigma$} & 39 & \\
\hline
\end{tabular}


312 AGREGAT: Jurnal Ekonomi dan Bisnis

Vol. 2, No. 2 September 2018

http://journal.uhamka.ac.id/index.php/agregat

p-ISSN: 2580-3360 e-ISSN: 2581-2874

DOI: 10.22236/agregat_vol1/is4pp306-323

Hal 306-323

Berkenaan dengan jumlah sampel masyarakat, secara kuantitatif hal ini sesuai dengan Dalil Limit Pusat (Central Limit Theorem) yang menyatakan bahwa apabila $X_{1}, X_{2}, \ldots X_{n}$ merupakan variabel acak dari populasi (dalam hal ini, distribusi probabilitas) manapun dengan rata-rata $\mu_{\mathrm{x}}$ dan varians $\sigma^{2} \mathrm{x}$, maka rata-rata sampel cenderung terdistribusi secara normal dengan rata-rata $\mu_{\mathrm{x}}$ dan varians $\frac{\sigma x^{2}}{n}$ ketika ukuran sampel naik hingga tak terhingga. Jika $X_{i}$ diasumsikan berasal dari populasi normal, maka rata-rata sampel akan mengikuti distribusi normal tanpa peduli terhadap ukuran sampel. Dalam praktiknya, terlepas distribusi probabilitas apapun yang mendasarinya, rata-rata sampel dari besaran sampel yang terdiri dari sekurang-kurangnya 30 observasi akan dijamin normal (Juanda, 2012).

Teknik analisis bagian ini terdiri dari 3 (tiga) bagian. Pertama adalah analisis nilai tengah (median) tarif retribusi yang bersedia dibayar oleh pengguna kios/lapak. Argumentasi penulis atas penggunaan formulai ini adalah disebabkan nilai media adalah gambaran nilai yang paling moderat yang dapat diterima oleh pengguna kios/lapak di pasar. Formula standar nilai median untuk data ganjil (formula 4) dan data genap (formula 5) adalah sebagai berikut.

$$
\begin{aligned}
& M e=X \frac{n+1}{2} \ldots \ldots \ldots \ldots \ldots . . . . . . . . \\
& M e=\frac{1}{2}\left(X\left(\frac{n}{2}+X \frac{n}{2}+1\right)\right)
\end{aligned}
$$

Kedua, selain menggunakan formula median, juga digunakan pendekatan kesediaan membayar (willingness to pay/WTP). Secara umum, nilai ekonomi didefinisikan sebagai pengukuran jumlah maksimum seseorang ingin mengorbankan barang dan jasa untuk memperoleh barang dan jasa lainnya. Secara formal, konsep ini disebut "keinginan membayar" (willingness to pay) seseorang terhadap barang dan jasa yang dihasilkan oleh pemerintah. Dengan menggunakan pengukuran ini, nilai barang dan jasa bisa "diterjemahkan" ke dalam bahasa ekonomi dengan mengukur nilai moneter barang dan jasa tersebut.

Keinginan membayar juga dapat diukur dalam bentuk kenaikan pendapatan yang menyebabkan seseorang berada dalam posisi indifferent terhadap perubahan eksogenus (faktor-faktor di luar yang bisa dikontrol). Perubahan ini bisa terjadi karena perubahan harga (misalnya akibat sumber daya makin langka) atau karena perubahan kualitas sumber daya. 
Jadi WTP dapat diartikan sebagai jumlah maksimal seseorang mau membayar untuk menghindari terjadinya penurunan terhadap sesuatu.

Banyak faktor mempengaruhi keputusan masyarakat untuk menikmati layanan pemerintah, salah satunya adalah kemampuan atau daya belinya. Daya beli sangat terkait dengan pendapatan masyarakat dan tarif retrbusi. Dalam ekonomik, permintaan masyarakat akan layanan pemerintah dapar diekspresikan dalam fungsi permintaan.

Fungsi permintaan adalah fungsi yang menunjukkan hubungan antara kuantitas layanan yang diinginkan masyarakat dengan tarif retribusi, pendapatan masyarakat, dan faktor lain. Ada dua cara yang dapat digunakan untuk mengestimasi fungsi permintaan, yaitu metode langsung dan metode tidak langsung. Metode langsung melibatkan konsumen dengan menanyakan secara langsung apa yang mereka lakukan jika terjadi perubahan dalam variabel tertentu.

Sedangkan metode tidak langsung dilakukan berdasarkan data yang telah dikumpulkan dan kemudian dilakukan upaya untuk menemukan hubunganhubungan statistik antara variabel. Dalam tahap operasional penerapan pendekatan CVM terdapat 5 tahap kegiatan atau proses. Tahapan tersebut adalah; Membuat hipotesis pasar, hipotesis pasar yang dibangun disini adalah Dinas Perindustrian dan Perdagangan ingin menentukan tarif retribusi pasar. Pada tahap ini konsultan membuat suatu kuesioner yang berisi informasi lengkap mengenai informasi harga (tarif) pasar bagi setiap pedagang/pengguna lapak dengan berdasar pada harga (tarif) retribusi di pasar yang dikelola oleh swasta; Mendapatkan nilai lelang (bids), tahap ini dilakukan dengan teknik survey langsung terhadap responden. Instrumen survey menggunakan kuesioner tertutup (model referendum) dengan jawabab "ya" dan “tidak". Tujuan survey ini adalah untuk memperoleh nilai maksimum keinginan membayar (WTP) dari responden terhadap tarif retribusi; Menghitung rataaan WTP, setelah survey dilakukan, tahap berikutnya adalah menghitungn nilai rataan setiap individu. Nilai ini diperoleh dari hasil lelang tahap dua. Perhitungan nilai WTP dengan menggunakan Contingent Valuation Method digunakan pendekatan model logit.

Model diestimasi dengan menggunakan Maximum Likelihood dimana peluang seseorang untuk membayar retribusi diasumsikan merupakan fungsi dari variabel sosial- 
314 AGREGAT: Jurnal Ekonomi dan Bisnis

Vol. 2, No. 2 September 2018

http://journal.uhamka.ac.id/index.php/agregat

p-ISSN: 2580-3360 e-ISSN: 2581-2874

DOI: 10.22236/agregat_vol1/is4pp306-323

Hal 306-323

ekonomi: jenis kelamin,pendapatan (income), dan kepuasan atas pelayanan pasar. Peluang menjawab ya $=1$ (sanggup membayar) atau tidak $=0$, ditentukan oleh persamaan regresi linier berikut ini:

$$
\begin{aligned}
& P\left(Y_{n}=1\right)=P\left(u_{i}>-\alpha-\beta X_{n}\right)=1-F\left(\frac{-\alpha-\beta X_{n}}{\sigma}\right) \ldots[6] \\
& P\left(Y_{n}=0\right)=P\left(u_{i} \leq-\alpha-\beta X_{n}\right)=1-F\left(\frac{-\alpha-\beta X_{n}}{\sigma}\right)_{. .[7]}
\end{aligned}
$$

Dimana koefisien $\alpha$ dan $\beta$ adalah koefisien regresi dengan $X$ adalah vektor variabel sosial-ekonomi (jenis kelamin, pendapatan/income, dan persepsi terhadap pelayanan fasilitas pasar). Pendugaan koefisien dilakukan dengan teknik maximum likelihood dengan fungsi sebagai berikut:

$$
L=\prod_{Y_{n}=0} F\left(\frac{-\alpha-\beta X_{n}}{\sigma}\right) \prod_{Y_{n}=1}\left[1-F\left(\frac{-\alpha-\beta X_{n}}{\sigma}\right)\right]_{\ldots[8]}
$$

Dari pendugaan koefisien pada persamaan [8] kemudian akan diperoleh nilai rataan willingness to pay (mean WTP) yang menggambarkan nilai tarif retribusi. Memperkirakan kurva lelang (Bid Curve) Kurva lelang atau bid curve diperoleh dengan meregresikan WTP sebagai variabel tidak bebas (dependen variabel) dengan variabel bebas seperti jenis kelamin, pendapatan (income), dan persepsi terhadap fasilitas pelayanan pasar dengan model sebagai berikut:

$$
W t_{i}=f(I, S, P) \ldots \ldots[9]
$$

Model [9] ditransformasi ke logaritma (log) sehingga:

$$
\begin{aligned}
\operatorname{LogWTP}_{i}= & \alpha_{0}+\beta_{1} \log \text { Income }_{i}+\beta_{2} \text { DummyGender } \\
& +\beta_{3} \text { DummyKepuasan } \\
& +\varepsilon \ldots \ldots \ldots \ldots \ldots[10]
\end{aligned}
$$

Mengagregatkan data, Tahap terakhir dari CVM adalah dengan mengagregatkan rataan lelang yang diperoleh pada tahap tiga. Proses ini melibatkan konversi data rataan sampel ke rataan populasi secara keseluruhan dengan rumus sebagai berikut:

$$
\overline{W t n} \times n
$$

Ketiga, Perbandingan harga pasar. Ada banyak layanan pemerintah yang banyak juga disediakan oleh swasta, seperti penyewaan ruangan, gedung, tanah, peralatan, dan lain sebagainya. Untuk kasus seperti ini, informasi harga pasar sewa bukan hal yang sulit didapatkan. Harga pasar sewa merupakan hasil dari tarik menarik antara permintaan dan penawaran pasar. Perbandingan harga pasar dapat dilakukan dengan melakukan survey terhadap barang/jasa sejenis. Dalam konteks pungutan retribusi, perbandingan harga pasar akan dilakukan terhadap pasar yang dikelola oleh swasta di Tangerang Selatan. 


\section{HASIL DAN PEMBAHASAN}

Secara teori, kesediaan membayar (willingness to pay) sangat erat kaitannya dengan pendapatan dan pelayanan yang diterima oleh seseorang. Dengan kata lain, kesediaan membayar seseorang adalah fungsi dari pendapatan dan kepuasan atas pelayanan yang diberikan.

Sebelum melakukan pendugaan dengan peralatan statistika, berikut ini adalah hasil jajak pendapat kepada pengguna kios/lapak tentang kesediaan membayar mereka. Informasi pada Gambar 5 menjelaskan pendapat responden tentang revitalisasi pasar. Sebanyak $38 \%$ pengguna kios/lapak menyatakan setuju bahwa pasar perlu direvitaliasi dalam upaya menghasilkan fasilitas pelayanan yang lebih baik. Bahkan sebanyak $36 \%$ pengguna kios/lapak menyatakan sangat setuju jika pasar direvitalisasi. Selebihnya sebesar $21 \%$ pengguna kios/lapak menyatakan netral dan $5 \%$ pengguna menyatakan ketidaksetujuannya. Informasi ini sesungguhnya mengindikasikan bahwa terdapat ekspektasi [harapan] dari para pengguna kios/lapak bahwa pasar dapat direvitalisasi di masa mendatang.

\section{Gambar 5. Pendapat Responden tentang Revitalisasi}

\section{Fasilitas Pasar}

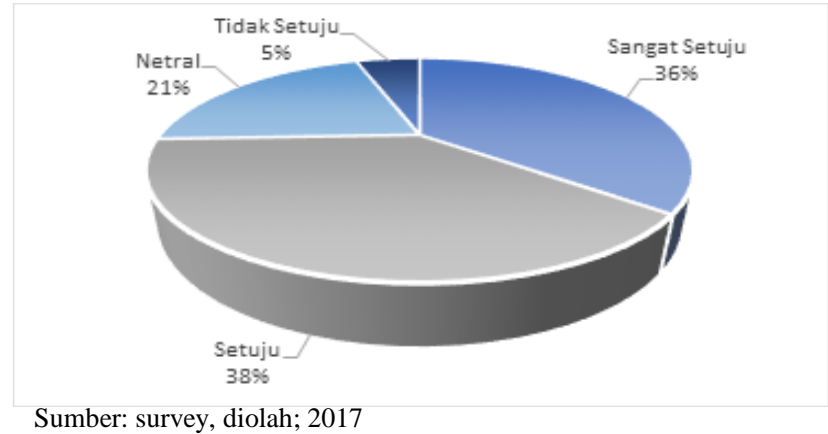

\section{Gambar 6. Pendapat Responden tentang Kesediaan Membayar}

\section{Retribusi Jika Fasilitas Pasar Bermutu}

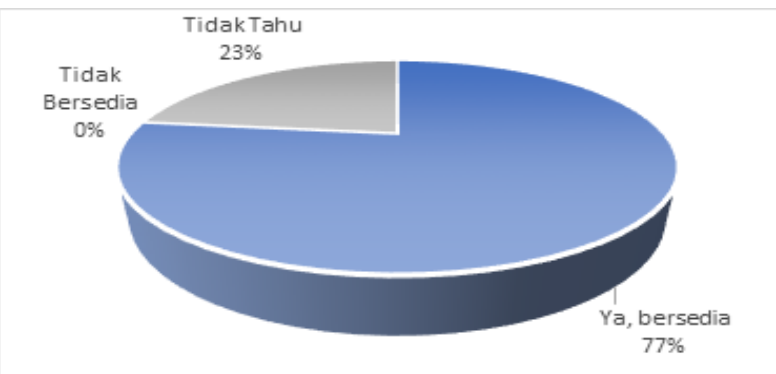


316 AGREGAT: Jurnal Ekonomi dan Bisnis

Vol. 2, No. 2 September 2018

http://journal.uhamka.ac.id/index.php/agregat

p-ISSN: 2580-3360 e-ISSN: 2581-2874

DOI: $10.22236 /$ agregat_vol1/is4pp306-323

Hal 306-323

Sumber: survey, diolah; 2017

Gambar 6 menjelaskan situasi kesediaan membayar para pengguna kios/lapak.

Sebanyak $77 \%$ pengguna menyatakan bersedia jika fasililtas pasar bermutu. Sebanyak $23 \%$ responden menyatakan tidak tahu. Hasil jajak pendapat ini

menyirat makna bahwa pengguna bisa memahami keterkaitan "mutu sebuah produk" dengan harga yang harus mereka bayar. Hasil ini relevan dengan studi yang dilakukan Wang et al (2016) di Korea Selatan.

\section{Gambar 7. Kesediaan Responden Membayar Retribusi \\ Lebih Tinggi Jika Fasilitas Pasar Direvitalisasi}

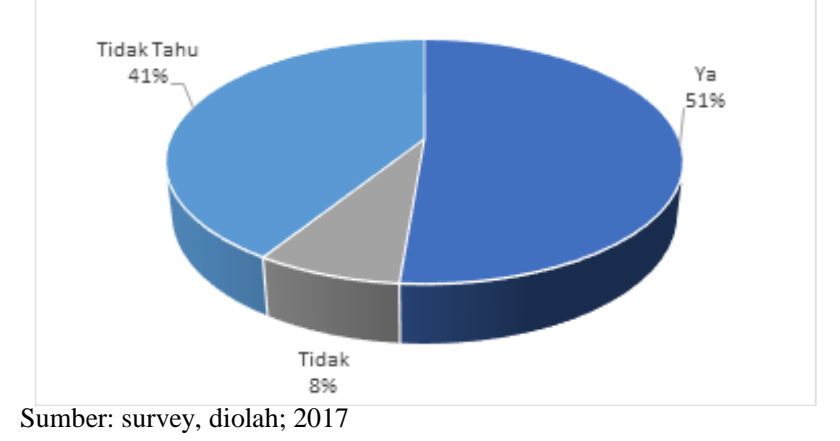

Lebih dari itu, pengguna bersedia kios/lapak dalam membayar retribusi. membayar retribusi lebih tinggi jika pasar Tanda koefisien yang diharapkan adalah direvitalisasi. Sebanyak $51 \%$ pengguna $\beta_{1}>0 ; \beta_{2}>0 ;$ dan $\beta_{3}>0$. Pendekatan yang kios/lapak menyatakan persetujuannya, $41 \%$ pengguna menjawab tidak tahu, dan sisanya sebesar $8 \%$ pengguna menjawab tidak bersedia. Informasi ini menjadi salah satu dasar pengambilan kebijakan bagi Dinas Perindustrian dan Perdagangan, terutama dalam menentukan besaran tarif retribusi di masa mendatang.

Dengan menggunakan persamaan [10] dalam Bab IV, diperoleh pendugaan kesediaan membayar [WTP] pengguna dilakukan adalah ordinary least square dengan model $\mathrm{Y}_{\mathrm{t}}=\alpha+\beta_{1} \mathrm{X}_{\mathrm{t}}+\varepsilon$ untuk $\mathrm{t}=$ $1,2 \ldots, \mathrm{i}$.

Dengan asumsi sebagai berikut (Juanda, 2009); Hubungan antara Y dan X adalah linear dalam parameter; Nilai $\mathrm{X}$ tetap untuk observasi yang ber-ulangulang (non-stocastic).

Karena variabel X-nya lebih dari satu, maka tidak ada multikolinieritas antara $\mathrm{X}_{1}$, $\mathrm{X}_{2}$, dan $\mathrm{X}_{\mathrm{n}}$; Nilai harapan (expected 
value) atau rata-rata dari variabel gangguan $\mathrm{e}_{\mathrm{i}}$ adalah nol atau $\mathrm{E}\left(\mathrm{e} \mid X_{\mathrm{i}}\right)=0$; Varian dari variabel gangguan $e_{i}$ adalah sama (homoskedastisitas)

$$
\operatorname{Var}\left(e_{i} \mid X_{i}\right)=E\left[e_{i}-E\left(e_{i} \mid X_{i}\right)\right]^{2}=E\left(e_{i}^{2} \mid X_{i}\right)=\sigma^{2}
$$

Tidak ada serial korelasi antara variabel gangguan $e_{i}$, atau variabel gangguan $e_{i}$ tidak saling berhubungan dengan variabel $\begin{array}{llll}\text { gangguan } & \mathrm{e}_{\mathrm{i}} \quad \text { yang }\end{array}$

$\left.\operatorname{Cov}\left(e_{i}, e_{j} \mid X, X_{i}\right)=E\left[\left(e_{-}-E\left(e_{i}\right) \mid X\right)\right]\right]\left[\left(e_{i}-E\left(e_{i}\right) \mid X_{i}\right)\right]$

$=E\left(e_{i} \mid X_{i}\right)\left(e_{j} \mid X_{i}\right)=0$

Variabel gangguan $\mathrm{e}_{\mathrm{i}}$ berdistribusi normal $\mathrm{e} \sim \mathrm{N}\left(0, \sigma^{2}\right)$

\section{Gambar 8. Kurva Kesediaan Membayar Tarif Retribusi}

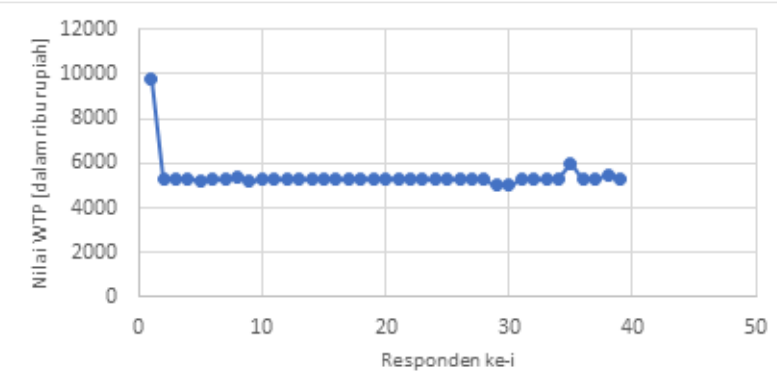

Sumber: data diolah, 2017

Hasil pendugaan awal menghasilkan nilainilai sebagaimana tersaji dalam Tabel 2 . Tabel ini menginformasikan bahwa hasil pendugaan terhadap variabel-variabel dalam model regresi tidak sesuai prinsipprinsip ekonometrika sebagaimana disebut dalam Juanda (2009) di atas. Hal tersebut terlihat dari variabel dummy jenis kelamin [D_Gender) dan kepuasan terhadap pelayanan pasar [D_Kepuasan]. Nilai p- value sebagai tolok ukur pengambilan keputusan menunjukkan hasil yang tidak signifikan. Rekomendasi teori statistik untuk menyiasati hal tersebut adalah dengan membuang variabel-variabel yang tidak Prosedur tersebut mengisyaratkan bahwa perlunya menguji kembali model regresi. Hasil pengujian dan pendugaan setelah membuang variabel yang tidak signifikan tersaji dalam Tabel 3.

Tabel 2. Hasil Pendugaan Awal Nilai Regresi Kesediaan Membayar Retribusi

\begin{tabular}{|c|c|c|c|c|c|c|}
\hline Variabel & $\begin{array}{l}\text { Simpangan } \\
\text { Baku }\end{array}$ & Koefisien & $\begin{array}{l}\mathrm{t}- \\
\text { hitung }\end{array}$ & P-Value & $\begin{array}{l}\text { Varians } \\
\text { Inflation }\end{array}$ & Keterangan \\
\hline
\end{tabular}


318 AGREGAT: Jurnal Ekonomi dan Bisnis

Vol. 2, No. 2 September 2018

http://journal.uhamka.ac.id/index.php/agregat

p-ISSN: 2580-3360 e-ISSN: 2581-2874

DOI: 10.22236/agregat_vol1/is4pp306-323

Hal 306-323

Factor

\begin{tabular}{lllllll}
\hline Konstanta & 0,212 & 3,264 & 15,42 & 0,000 & -- & -- \\
LogIncome & 0,0358 & 0,0787 & 2,20 & 0,035 & 1,02 & Signifikan \\
D_Gender & 0,0143 & 0,0006 & 0,04 & 0,967 & 1,02 & Tidak signifikan \\
D_Kepuasan & 0,0142 & 0,0119 & 0,84 & 0,407 & 1,02 & Tidak signifikan \\
\hline $\mathrm{R}^{2}$ & $14,45 \%$ & & & & \\
$\mathrm{R}^{2}$ Adj & & $6,90 \%$ & & & & \\
Durbin Watson [DW] & 1,072 & & & & \\
\hline \multicolumn{7}{l}{ Sumber: data diolah; 2017}
\end{tabular}

Tabel 3. Hasil Pendugaan Nilai Regresi Kesediaan Membayar Retribusi

\begin{tabular}{lllllll}
\hline Variabel & $\begin{array}{l}\text { Simpangan } \\
\text { Baku }\end{array}$ & Koefisien & t-hitung & $\begin{array}{l}\text { P- } \\
\text { Value }\end{array}$ & $\begin{array}{l}\text { Varians } \\
\text { Inflation } \\
\text { Factor }\end{array}$ & Keterangan \\
\hline Konstanta & 0,198 & 3,314 & 16,77 & 0,000 & -- & -- \\
LogIncome & 0,0334 & 0,0709 & 2,12 & 0,041 & 1,00 & Signifikan \\
\hline $\mathrm{R}^{2}$ & & $10,84 \%$ & & & & \\
$\mathrm{R}^{2}$ Adj & $8,43 \%$ & & & & \\
Durbin Watson [DW] & 1,07997 & & & & \\
\hline Sumber: data diolah: 2017 & & & & &
\end{tabular}

Hasil pengujian dan pendugaan pada Tabel

3 menginformasikan bahwa model regresi

telah signifikan sebagai dasar pengambilan keputusan.

Sehingga persamaan WTP retribusi dapat ditulis sebagai berikut:LogWTP = $3.314+0.0709$ LogI. Di mana WTP adalah kesediaan membayar, dan I adalah pendapatan (Income) pengguna kios/lapak. Dugaan koefisien pendapatan (income) terhadap WTP adalah positif. Nilai koefisien menunjukkan 0,0709 (7,1\%).

Nilai ini memiliki arti setiap perubahan (peningkatan) pendapatan sebesar $1 \%$ pengguna kios/lapak akan meningkatkan probabilitas kesediaan membayar retribusi sebesar $7,1 \%$. Variabel pendapatan (I) dalam model regresi ini mampu menjawab keragaman kesediaan membayar $\left(\mathrm{R}^{2}\right)$ sebesar $10,8 \%$; dan $89,2 \%$ dijelaskan oleh variabel lain yang tidak 
dimasukkan ke dalam model. Hasil ini memberi informasi bahwa sesungguhnya terdapat hubungan kausatif yang nyata antara peningkatan pendapatan pengguna kios/lapak dengan kesediaan mereka dalam membayar retribusi. Semakin tinggi pendapatan mereka, semakin tinggi pula kemungkinan mereka mampu dan bersedia membayar retribusi. Hasil ini menjadi justifikasi bagi Dinas Perindustrian dan Perdagangan dalam mengambil kebijakan peningkatan tarif retribusi di masa mendatang. Adapun besaran tarif retribusi menurut hasil jajak pendapat tersaji dalam Tabel 4.
Tabel 4 menginformasikan nilai ratarata besaran tarif retribusi yang bersedia dibayar oleh para pengguna kios/lapak adalah Rp. 5.440 per hari; dengan nilah tengah (median) harga yang bersedia mereka bayar adalah Rp. 5.250/hari. Rekomendasi konsultan atas temuan ini adalah Dinas Perindustrian dan Perdagangan dapat mengambil kebijakan tarif berdasarkan dengan nilai tengah (median) yang bersedia pengguna kios/lapak bayar karena nilai tengah menggambarkan nilai paling moderat ketimbang nilai rata-rata.

Tabel 4. Rata-Rata Besaran Retribusi yang Bersedia dibayar oleh Pengguna

Kios/Lapak

\begin{tabular}{|c|c|c|}
\hline No & Komponen & Jumlah [Rp]/hari \\
\hline 1 & $\begin{array}{l}\text { Rata-Rata harga retribusi yang bersedia dibayar pengguna } \\
\text { kios/lapak }\end{array}$ & 5.440 \\
\hline 2 & $\begin{array}{l}\text { Nilai tengah harga retribusi yang bersedia dibayar } \\
\text { pengguna kios/lapak }\end{array}$ & 5.250 \\
\hline 3 & Harga lain-lain* & \\
\hline & a. Kebersihan & 3.500 \\
\hline & b. Keamanan & 3.000 \\
\hline & c. Listrik & 3.000 \\
\hline$\sum^{* *}$ & & 14.750 \\
\hline
\end{tabular}

Selanjutnya, hasil survey lapangan retribusi, yaitu uang kebersihan, uang menunjukkan bahwa pengguna kios/lapak listrik, dan uang keamanan. Karena itu, dikenakan pungutan lain selain dari jika diagregasi (ditotal) harga retribusi 
320 AGREGAT: Jurnal Ekonomi dan Bisnis

Vol. 2, No. 2 September 2018

http://journal.uhamka.ac.id/index.php/agregat

p-ISSN: 2580-3360 e-ISSN: 2581-2874

DOI: $10.22236 /$ agregat_vol1/is4pp306-323

Hal 306-323

yang harus dibayar oleh pengguna adalah sebesar Rp. 14.750/hari. Penentuan tarif retribusi juga dilakukan dengan metode perbandingan harga pasar. Pasar yang menjadi alat perbandingan adalah Pasar Modern Bintaro yang berlokasi di Jalan Pondok Aren, Pd. Jaya, Pd. Aren, Kota Tangerang Selatan. Hasil survey yang penulis dengan teknik wawancara terhadap pedagang yang terdapat di Pasar Modern Bintaro menghasilkan informasi yang tersaji dalam Tabel 5.

Tegal Rotan Raya No.2, Pondok Jaya,

\section{Gambar 9. Pasar Modern Bintaro}
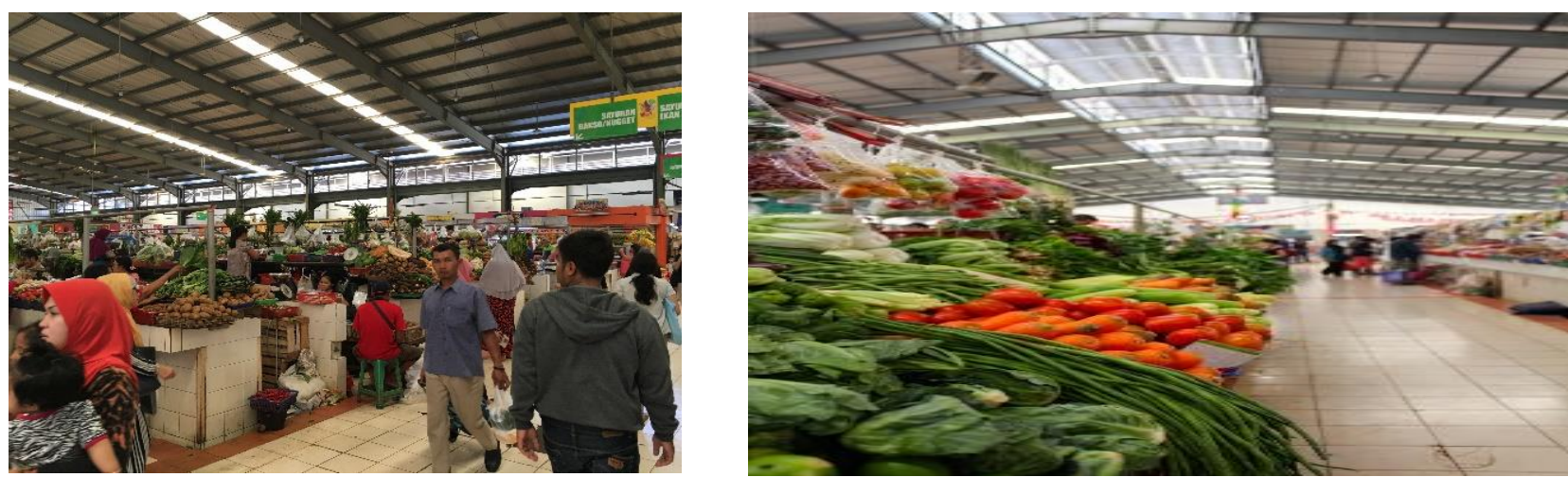

Sumber: survey, 2017

Tabel 5. Harga/Tarif Retribusi di Pasar Modern Bintaro

\begin{tabular}{ll}
\hline Jenis Lapak & Tarif per Bulan [Rp] \\
\hline Lapak/los sayur & $1.000 .000-1.300 .000$ \\
Lapak/los ikan & 2.500 .000 \\
Kios & 3.750 .000 \\
\hline Sumber: survey, 2017 & \multicolumn{2}{l}{$\begin{array}{l}\text { Selatan jauh lebih murah. Informasi pada } \\
\text { Jika dibandingkan }\end{array}$ dengan tarif } & Tabel 27 dan 28 kemudian dapat dihitung \\
retribusi di Pasar Modern Bintaro, tentu & perbandingan harga pasarnya sebagaimana \\
harga/tarif retribusi pasar tradisional yang & $\begin{array}{l}\text { tersaji dalam tabel berikut. } \\
\text { dimiliki oleh Pemerintah Kota Tangerang }\end{array}$
\end{tabular}

Tabel 6. Perbandingan Tarif Retribusi Pasar yang Dimiliki Swasta dan Pemerintah Kota Tangerang Selatan

Jenis Pasar Berdasarkan Kepemilikan

Jumlah Tarif $[\mathrm{Rp}]$ per

Hari 
Pasar tradisional yang Dimiliki Pemerintah Kota Tangerang 14.750

Selatan

Pasar yang Dimiliki Swasta*

Sumber: [*] survey; data diolah, 2017; Keterangan: [*] berdasarkan nilai rata-rata lapak/los sayur dan ikan

Pada Tabel 6 terbaca bahwa tarif retribusi pada pasar tradisional yang dimiliki pemerintah lebih murah dibandingkan dengan tarif retribusi pada pasar yang dimiliki oleh swasta. Dengan memperhatikan data tersebut, maka sesungguhnya, penentuan tarif retribusi sebesar Rp. 14.750/hari pada pasar tradisional yang dimiliki Pemerintah Kota Tangerang Selatan masih sangat layak untuk diterapkan. Namun demikian, tarif tersebut tentu memiliki prasyarat yang harus dipenuhi, yaitu: (1) fasilitas pasar bermutu; dan (2) sistem governance pasar terkelola dengan baik.

Menurut Sulistyo \& Cahyono (2010), dalam upaya mewujudkan peningkatan kontribusi pasar terhadap PAD, pasarpasar tradisional harus dibuat lebih modern dahulu untuk menuju pasar yang sehat dan bisa berkontribusi pada perekonomian daerah. Dengan kata lain, tindakan revitaliasi menjadi agenda pertama yang harus diselesaikan (Paramita, 2010).

\section{SIMPULAN}

Hasil jajak pendapat terhadap pengguna kios/lapak menunjukkan bahwa sejatinya mereka bersedia membayar retribusi lebih tinggi jika pasar dapat direvitalisasi dan diberi fasilitas yang bermutu. Hasil uji statistika terhadap kesediaan membayar mereka [willingness to pay] menunjukkan, terdapat hubungan kausal yang nyata antara peningkatan pendapatan yang mereka terima dengan kesediaan membayar retribusi. Hasil uji model regresi mengonfirmasi, peningkatan pendapatan pengguna kios/lapak sebesar $1 \%$ akan meningkatkan probabilitas kesediaan membayar retribusi sebesar $7,1 \%$. Dengan kalimat yang lain, semakin tinggi pendapatan mereka, semakin tinggi pula kemungkinan mereka mampu dan bersedia membayar retribusi. Hasil ini menjadi justifikasi bagi Dinas Perindustrian dan Perdagangan dalam mengambil kebijakan peningkatan tarif retribusi di masa mendatang.

Hasil kalkulasi juga menunjukkan, nilai retribusi yang bersedia mereka bayar berkisar pada harga Rp. 14.750 per hari. Harga ini telah termasuk di dalamnya uang kebersihan, uang listrik, dan uang keamanan. Dengan menguji validitas 
322 AGREGAT: Jurnal Ekonomi dan Bisnis

Vol. 2, No. 2 September 2018

http://journal.uhamka.ac.id/index.php/agregat

p-ISSN: 2580-3360 e-ISSN: 2581-2874

DOI: 10.22236/agregat_vol1/is4pp306-323

Hal 306-323

perbandingan harga tersebut pada pasar yang dikelola swasta, harga sebesar Rp. 14.750 per hari masih jauh di bawah harga pungutan retribusi pasar yang dikelola swasta, yaitu sebesar Rp. 53.333 per hari. Dengan memperhatikan hasil tersebut, maka sesungguhnya, penentuan tarif retribusi sebesar Rp. 14.750/hari pada pasar tradisional yang dimiliki Pemerintah Kota Tangerang Selatan masih sangat layak untuk diterapkan dengan prakondisi sebagai berikut: (1) fasilitas pasar bermutu; dan (2) sistem governance pasar terkelola dengan baik.

\section{REFERENSI}

Basri, M.C., et al, (2012), Rumah Ekonomi Rumah Budaya: Membaca Kebijakan

Perdagangan Indonesia, Jakarta:

Penerbit Gramedia.

Firmanzah, R.E., \& Halim, (2012), Strategi Revitalisasi Pasar

Tradisional, dalam Basri, M.C., et al, (2012), Rumah Ekonomi Rumah Budaya: Membaca Kebijakan Perdagangan Indonesia, Jakarta: Penerbit Gramedia

Haidar, J.I., (2012), The Impact of Business Regulatory Reforms on Economic Growth, Journal of the Japanese and International Economies, 26 (2012): 285-307.
Handoko, A.T., (2012), Analisis Perkembangan Retribusi Pasar Daerah sebagai Sumber Pembiayaan Otonomi Daerah di Kab. Pemalang Tahun 2007-2011, Economics Development Analysis Journal, 1 (2) (2012): 1-7.

Juanda, B., (2009), Ekonometrika: Pemodelan dan Pendugaan, IPB Press, Bogor.

--------., (2012), Metodologi Penelitian Ekonomi dan Bisnis, Bogor: IPB Press.

Juliarta, I.M.G., \& Darsana, I.B., (2015), Analisis Efektivitas Revitalisasi Pasar Tradisional Dan Dampaknya Terhadap Pengelolaan Pasar, Jumlah Pengunjung Dan Pendapatan Pedagang. E-Jurnal Ekonomi Pembangunan Universitas Udayana. Vol. 5, No. 1 138-166.

Khitam, M.C., (2014), Pelayanan Publik di Daerah Otonom Baru (Studi Pelayanan Bidang Pendidikan dan Kesehatan), Jurnal EKBIS, Vol. XI/ No. 2, Juli 2014: 553-567.

Marselina, E., (2013), Analisis Kontribusi Pajak Parkir dan Retribusi Pasar terhadap Pendapatan Asli Daerah pada Pemerintah Kota Padang, 
Jurnal Akuntansi, Vol. 1, No. 1: 125 .

Masitha, A.I., (2010), Dampak Sosial Ekonomi Revitalisasi Pasar

Tradisional terhadap Pedagang, Jurnal Sosek Pekerjaan Umum, Vol. 2, No. 1, April 2010: 41-55.

Megawati, N.A., \& Soejoto, A., (2016),

Kontribusi Retribusi Pasar terhadap

Pendapatan Asli Daerah (PAD)

Kabupaten Sidoarjo, Jurnal

Pendidikan Ekonomi, Vol. 4, No. 3: $1-10$.

Paramita, A.A. et al., (2013). Efektivitas

Dan Dampak Program Revitalisasi

Pasar Tradisional Di Pasar Agung

Peninjoan. E-Jurnal EP Unud, 2 (5)

233-243 ISSN: 2303-0178.

Prakosa, K.B., (2005), Pajak dan Retribusi

Daerah, Yogyakarta: UII Press

Putra, R.D.D., \& Rudito, B., (2015),

Planning Community Development

Program of Limbangan Traditional

Market Revitalization with Social

Mapping, Procedia-Social and

Behavioral Sciences, 169 (2015): 143-150.

Saragih, J.P. (2002). Desentralisasi

Fiskal dan Keuangan Daerah dalam

Otonomi. Jakarta: Penerbit Ghalia.

Smadja, O.P., \& Torre, A., (2017), Retail decentralization and land use regulation policies in suburban and rural communities: The case of the Ile-de-France region, Habitat International $\mathrm{xxx}$ (2017): 1-12.

Sugianto. (2008). Pajak dan Retribusi Daerah (Pengelolaan Pemerintah Daerah Dalam Aspek Keuangan, Pajak dan Retribusi Daerah). Jakarta: PT Gramedia Widiasarana.

Sulistyo, H., \& Cahyono, B. (2010) Model Pengembangan Pasar Tradisional Menuju Pasar Sehat di Kota Semarang. Jurnal EKOBIS Vol.11, No.2, Juli 2010 : 516 - 526.

Suryadarma, D., Poesoro, A., Akhmadi, Budiyati, S., Rosfadhila, M., Surhayadi, A., (2010), Traditional Food Traders in Developing Countries and Competition from Supermarket: Evidence from Indonesia, Food Policy, 35 (2010): 79-86.

Wang, H., Kim, K.H., Ko, E., Liu, H., (2016), Relationship Between Service Quality and Customer Equity in Traditional Markets, Journal of Business Research, xxx (2016): Xxx-Xxx. 